\title{
PERCEPTION OF CULTURAL HERITAGE AND \\ MONUMENT PROTECTION
}

\section{VITO HAZLER}

The paper highlights the importance of a comprehensive treatment of cultural heritage which contributes to the possibility of interdisciplinary cooperation between various human, social and natural disciplines. In addition to cooperation of different branches a successfulphysical renovation requires also the understanding of skills and technologies for processing materials from the past, that is from the time when an individual protected monument was built. The protection of immaterial heritage in the present time is closely linked to this finding and is more and more often applied in monument protection activities. Without taking into consideration the skills and knowledge from the past we cannot perform quality renovations of cultural monuments nor ensure basic ethic principles of monument protection of professional and amateur conservators in the field.

Keywords: comprehensive treatment of cultural heritage, identification, assessment, expert ethics, prejudice, presentation, interpretation, eco-museum.
Članek osvetljuje pomen celostne obravnave kulturne dediščine, ki prispeva $k$ možnosti interdisciplinarnega sodelovanja različnih humanisticnnih, družbenih in naravoslovnih znanosti. Uspešna fizična obnova poleg sodelovanja različnih ved zahteva tudi razumevanje veścin in tehnologij obdelave gradiv v času, ko je bil zgrajen zašciteni spomenik. Varstvo nesnovne dedišcine danes je stem tesno povezano in tudi vse bolj uporabljeno $v$ dejavnosti zaścite spomenikov. Brez upoštevanja preteklih vešcin in znanja ni mogoča kakovostna prenova kulturnih spomenikov, prav tako pa brez tega ni mogoče zagotoviti osnovnih etičnih načel poklicnega in amaterskega varovanja na terenu.

Ključne besede: celostna obravnava kulturne dediščine, identifikacija, vrednotenje, strokovna etika, predsodek, predstavitev, interpretacija, eko-muzej.

The necessity and essentiality of a comprehensive study of cultural heritage is becoming evident in all types of protection activities. Ethnologists, above all others, endeavour for the application of such a comprehensive study. They see it as an opportunity for the establishment of new effective methodological and programme premises, essential for the introduction of a comprehensive perception of heritage. In the past, the latter was perceived exclusively as one-sided and studied merely from the aspects of time, artistic expressiveness or architectural significance. The comprehensive study of cultural heritage, addressed in the last Slovenian Cultural Heritage Protection Act (Official Gazette no. 16/2008), introduces new possibilities for interdisciplinary work. And what is even more important, it helps promote prevailing doctrines (at least among ethnologists) that the protection and renovation of cultural heritage cannot be successful without having relevant knowledge on historical technological skills. The same Act envisages different possibilities for record keeping and for the establishment of a register of the so-called live heritage (Sln. živa dedišcina). This type of heritage is extremely important for the attainment of the end objective in protection and renovation procedures, which is a well-renovated cultural monument. 


\section{SYNERGY BETWEEN THE MATERIAL AND IMMATERIAL CULTURAL HERITAGE}

Live heritage, defined in the mentioned Act, is understood by a majority of Slovenian ethnologists as intangible heritage, which comprises of a variety of activities, knowledge, skills, capabilities, rituals and other cultural elements from material, social and spiritual culture that are important for comprehensive identification, assessment and protection of cultural heritage. Its importance is also becoming ever more evident in various developmental, economic, cultural, social, educational and event tourist activities (only if we consider this type of heritage as a specific component of tourism).

The close synergy between the tangible and intangible heritage becomes clear when the questions of autochthony and authenticity as well as restoration and reconstruction are addressed.

Without having sufficient qualitative and quantitative knowledge on tangible and intangible heritage, it is difficult to imagine successful monument protection or, more precisely, renovation of castles, churches, houses, mills, granaries and other remains of the past. The implementation of complex protection activities requires a great deal of experience and knowledge concerning cultural heritage that the holders of renovations acquire on a regular basis from both the newest scientific findings from different natural, technical, biotechnical and human sciences and directly from the field, that is from persons possessing certain knowledge and skills. This contributes to the development of a complex perception of cultural heritage which is not a novelty in Slovenia.

\section{COMPREHENSIVE TREATMENT OF HERITAGE AND ASSESSMENT CRITERIA}

For a number of decades now, Slovenian ethnologists have been highlighting the necessity of a comprehensive study of heritage. The programme content of this comprehensive approach with extended methodology gained its final form in the mid nineteen-nineties of the twentieth century. At that time, a concept on the formation of key standards for the identification, assessment and physical renovation of cultural heritage was formed in a circle of ethnologists and conservators. Based on their previous experience with monument protection, ethnologists developed relatively useful criteria which were implemented as guidance for the systemic protection of cultural heritage. To this end, the author of the article, an ethnologist and curator of several years, developed a set of criteria: geographical or spatial, historical or temporal, artistic or aesthetic, ethnological and social, construction and developmental. The functional, skills and knowledge and the artistic creativity criteria were added subsequently. The main substantial characteristics of individual standards are as follows:

The spatial or geographical criterion is important, as it highlights the occurrence of heritage in relation to geographical width and length and altitude. It is common knowledge 
that the ancient buildings in the Alpine world were made of different stone and wood than the buildings in the Pannonia area, where clay, easily accessible in nature, was also used for construction. Another difference is the structure of the houses. Because the natural living conditions in that area are very severe - it is windier and winters are very rich in snow the houses in the Alpine world had smaller or fewer openings. This explains why hayracks with "transparent" construction cannot be found at the altitude of $800 \mathrm{~m}$ and why only closed type hayracks for hay storage could be found on meadows and farms. Altitude presents a limitation for the development of viticulture as well; hence vineyards and vineyard buildings in Slovenia cannot be found over an altitude of approximately $500 \mathrm{~m}$. Similarly, fruit-growing and the once widespread fruit drying activity in the characteristic frnjače or pajštve are limited to no more than $800 \mathrm{~m}$ above sea level. To sum up, geographical location is essential for the recognition and assessment of buildings heritage.

However, comprehensive understanding of cultural heritage is not possible without taking into account the historical or temporal criteria. The latter helps experts to determine the position of a certain cultural phenomena on a time scale. This serves as one of the aspects for the establishment of the identification and assessment protocols. Another important criterion is the ethnological and social criterion, for there is nothing more interesting to ethnologists than the phenomenon of heritage in its social and professional context.

There follows the artistic or aesthetic criteria, which is based on an art historical analysis of styles. This criterion is most applicable in cases where no written, pictorial or any other sources can be found; by the application of a style analysis the researcher tries to identify the artistic style which helps him determine the approximate age of the examined facility.

The construction development criterion is multilayered in content and helps the researcher to place the studied facility on a scale of architectural development. In practice this means that facilities classified as the oldest houses are those in which the fireplace is located on the ground in the centre of a room (Sln. ognjišnica). These are followed by houses with a lifted fireplace and a furnace next to the wall or in a corner (Sln. dimnica) and houses with a "black" kitchen, which is separated from other "white" (clean) premises and houses with light (white) kitchens with chimney installations and built-in or transportable metal stoves. In addition to other things, this criterion covers the placement of a building on a building plot (e.g. single storey and multi-storey buildings and buildings built over a cellar) and the proportion between the woodwork and the stone in the building frame (stone buildings, partially stone buildings and wooden buildings).

The functional criterion is likewise important for a comprehensive study of heritage. It is used to carry out an analysis the genesis and the development of the facility's function and its premises. As these functions often change over time, the results of such analyses help curators to choose the most appropriate function: that is a function which would not be incompatible with the characteristics of the renovated facility.

In the last few years, the criterion of skills, knowledge and artistic creativity has been introduced into the modern conservation discipline. Researchers and conservators use this 
criterion to analyse historical technological procedures. They also benefit of it to select the most appropriate techniques, methods of approach and materials which are essential for a quality renovation of cultural heritage. Part of this research is the collection of data on craftsmen and artisans who still master older techniques of processing natural construction materials. At the same time, the database in the Register of intangible heritage is growing. ${ }^{1}$ Due to the use of natural construction materials and compliance with traditional knowledge and skills, the quality of monument renovation is improving. At the same time there are less and less possibilities for the implementation of the increasingly widespread poorly planned renovations from a professional point of view which in fact are destroying cultural heritage.

\section{PREJUDICE AGAINST THE EQUALITY OF DIFFERENT DISCIPLINES}

Ethnologists are convinced that the mentioned criteria are a precondition for a comprehensive study of cultural heritage and a basis for interdisciplinary work. However, the latter somehow fails to be applied in a variety of institutional settings of cultural heritage protection, museums and in particular at the national Institute for the Protectionof Cultural Heritage of Slovenia and its seven regional units. Here, we are confronted with a several year long bias against the equal participation of all disciplines that are involved in monument protection activities. We also witness the favouring of certain privileged disciplines, such as art history, architecture, landscape architecture and archaeology. In these institutions ethnologists and ethnology are given only tasks related to folk, rural, working class and mass architecture. It is evident that such division of expertise work is controversial and far from the principles supported by the Cultural Heritage Act of 2008.

\section{ETHICS IN CULTURAL HERITAGE PROTECTION}

The issue of ethics should also be addressed in relation to the mentioned bias and one-sided distribution of protection tasks. This basic principle of "healthy" operation refers to society as a whole, the discipline and, of course, its users. It seems at times that rough interventions even in the essence of cultural monuments are no longer recognised as arguable. Not to mention the spatial types of modifications and the planned use of all kinds of technological equipment and novelties. Often the reason lies in the promoted artistic assessment of cultural heritage and the evaluation of facilities according to their significance and the current condition of the construction. Ethnologists are convinced that the Kolizej Palace in Ljubljana would not be demolished if it were treated in a comprehensive way and if all

1 Currently, the preparation of the Register is supervised by the Slovene ethnographic museum appointed by the Republic of Slovenia Ministry of Education, Sicence, Culture and Sport. 


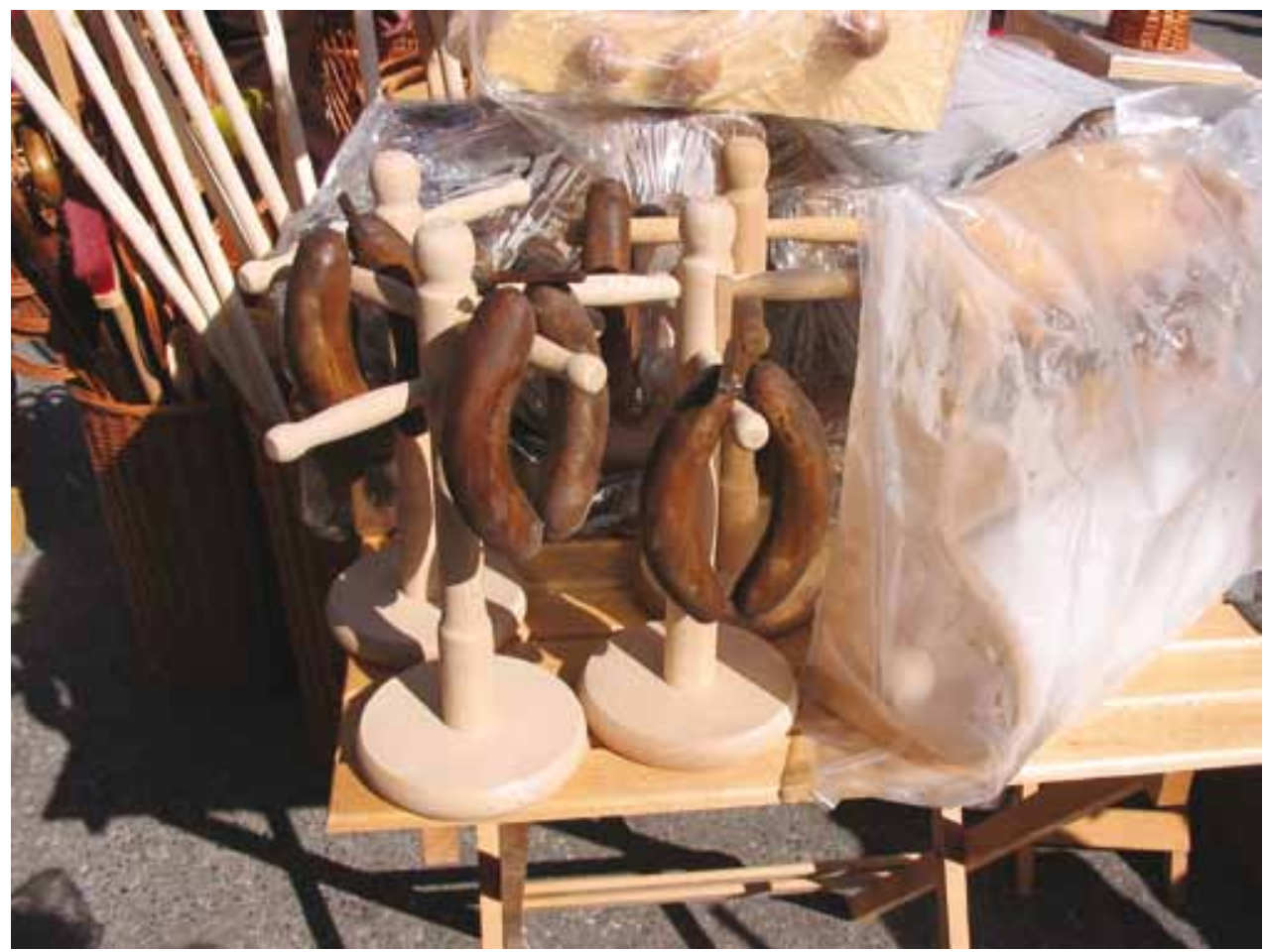

Figure 1. Ribnica in the Dolenjska region, Ribnica fair of woodenware and pottery. Wooden sausages (kranjska klobasa), presented at the fair, are highly debatable. Similarly questionable would be a total redirection from woodenware craft to the production of plastic products. The latter would undoubtedly cause polemics about the trivialization of cultural heritage (photo: V. Hazler, 2004).

disciplines taking part in monument protection, including ethnology, were allowed equal participation.

A quality level of business and professional ethics and the ethics of the amateurs are closely linked with the present reception and perception of cultural heritage. If the experts and the public do not have a clearly formed sense of ethics regarding heritage as a part of national or state capital, then this sense is underdeveloped and sometimes also contributes to distorted identification, assessment and interpretation of cultural heritage. Far too often the interpretation of heritage stresses its exceptionality, attractiveness, extraordinariness and speciality, which leads to its devaluation or even trivialisation.

Within this context we should highlight the need for reconstruction of monument complexes, currently completely or partially in ruins or strongly modified, which is disputable from the expert point of view. The Chartusian Monastery in Žiče (Žička kartuzija) and the so-called Lower Castle in Celje are examples of such ethically disputable monument protection decisions with distinctive romantic and nostalgic assessment. Based on the plans prepared by monument protection experts and the amateur public the mentioned facilities 


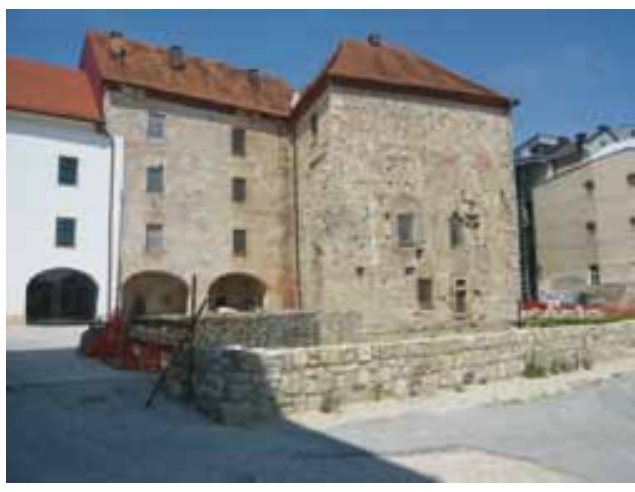

Figure 2. Celje, the Lower Castle. The archaeological site and the castle's facade do not seem very promising from conservation aspect. Seeing the castle in such state, a random uninformed visitor would not be able to recognize the quality of the facility. The Lower Castle has but a few visitors, even though it could be an attractive tourist point of the Celje tourist district also in its current state (naturally if all heritage elements would be appropriately presented) (photo: $\mathrm{V}$. Hazler, 2012).

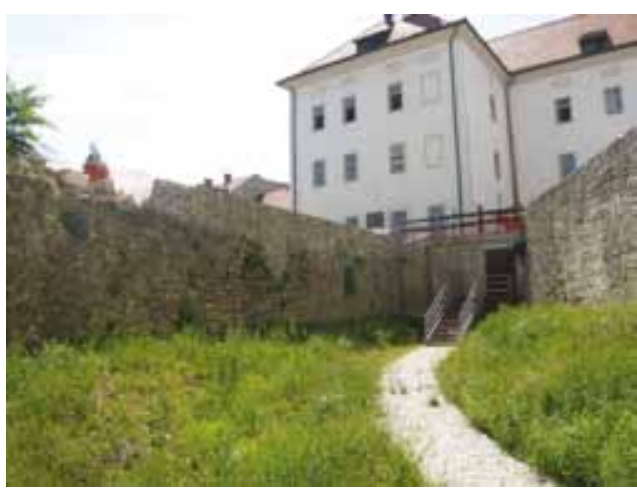

Figure 3. Celje, the Lower Castle. An overgrown archaeological excavation site may be interesting for experts, but tourist find it less interesting (photo: V. Hazler, 2012). were reconstructed following their original (sic) image. However, it is clear that the question of what was an original image is open for debate. In many places in the world such attempts have already been abandoned. The ruined monuments are thus presented in their present natural condition - as totally or partially in ruins. Such a protection approach is ethically correct and does not raise expert doubts, but enables possibilities for ethically indisputable modern reception and perception of cultural heritage in its historical communicative dimensions.

The ethic of an expert approach is being challenged in particularly through the implementation of new, contemporary elements into historical monument substances. The number of such cases in Slovenia is rising. They often have a negative influence on the comprehensive perception of culture and the displayed cultural monuments. The defenders of such solutions stress the importance of an unambiguous distinction between the old, basic, new or between those parts of a renovated monument that were added or supplemented. The planners of the Ljubljana opera house renovation and the extension construction acted in this way. Something similar happened in the Pleterje Monastery where a reception area with a store made entirely of glass and metal was constructed at the entrance. The same principle was followed by the renovators of the once picturesque municipal colony in Trbovlje (Občinska kolonija), where a functional environment of colony houses were modernised with asphalt parking places and decorative lawns. The modernisation took away its signature gardens and its unbridled self-development. The renovators completely neglected the functional and social element of the colony - an openair brick oven. To make the renovation more appealing the external wooden staircases and wooden balconies were glazed and surrounded with metal furniture and large glass screens. 


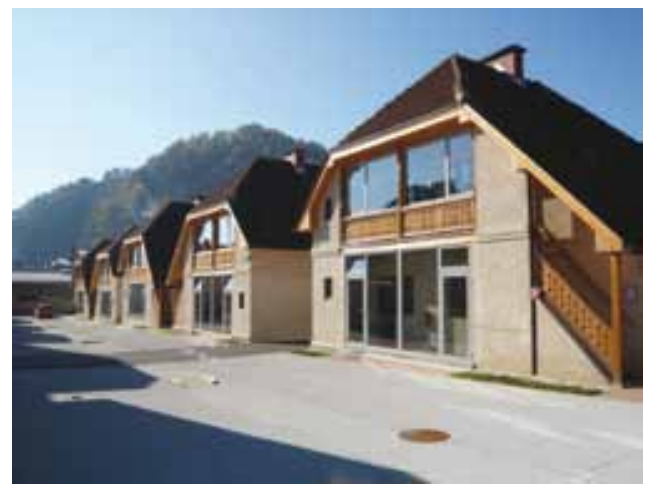

Figure 4. Slovenians being proud that $63 \%$ of their country is covered with forests find it difficult to accept the newly "renewed" municipal colony in Trbovlje. Never before has this place seen houses that were glazed with metal builder's joinery. The reason for the undertaking of such renovation procedures was the belief that the new renovation "additions" should be easily identifiable. Unfortunately this became the opposite of the intended, because, now, after the renovation, the "colony" seems as a series of modern summer houses from somewhere in the upper Sava Valley (photo: V. Hazler, 2010).

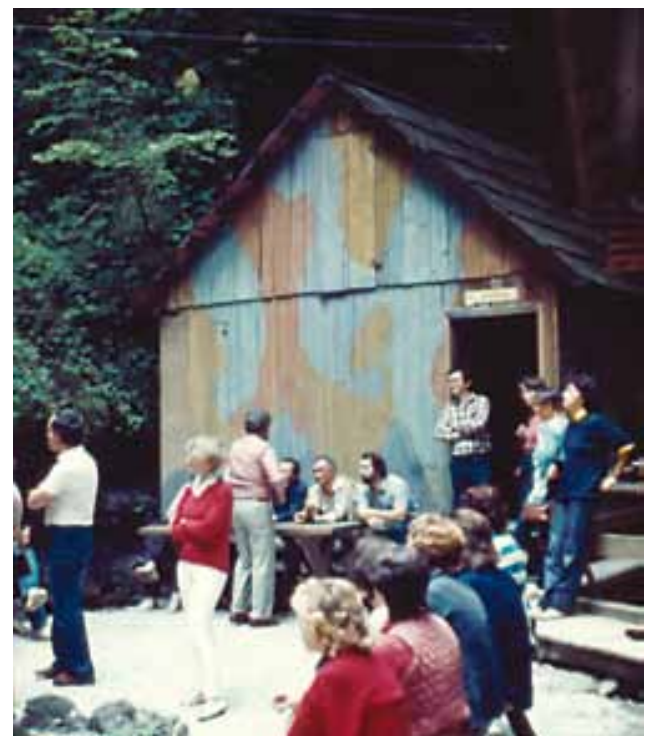

Figure 5. The Franja Partisan Hospital, 1983. The wooden buildings were painted in "blue military colours" for protection purposes (photo: V. Hazler, 1883).
Similar renovation methods were used by the planners of the Franja Partisan Hospital reconstruction; 14 out of 16 wooden barracks were completely ruined in a rainstorm on 18 September 2007. The ruined barracks were nicely reconstructed. However, new metal protective fences made of stainless metal were built where originally there was no protection. In addition, the installation of TVs in barracks does not contribute to the integrity and to the narrativity of the protected partisan hospital. In this case the ethic of the expert approach was greatly challenged. Therefore the question on how such actions influence the modern reception and perception of cultural heritage and consequently the strengthening of the awareness about its integral and undisputable preservation from the expert aspect are more than justified.

However, ethics can also have other substantial dimensions. Members of a certain discipline might be tempted to abuse these ethical principles. Such an example occurred more than twenty years ago in the assessment of achievements at the construction of the Rogatec Open-Air Museum. In the years 1993 and 1994, two student research workshops were organised in the museum in cooperation with the Museum of Recent History Celje. The purpose of the workshops was to obtain new knowledge and findings about various forms of economic and cultural life in the places south of the Donačka gora under the mentorship of eminent experts. Both workshops were relatively successful. However, at the first workshop, in 1993, a group of young researchers stood out with their provocative operation which under the mentorship of 


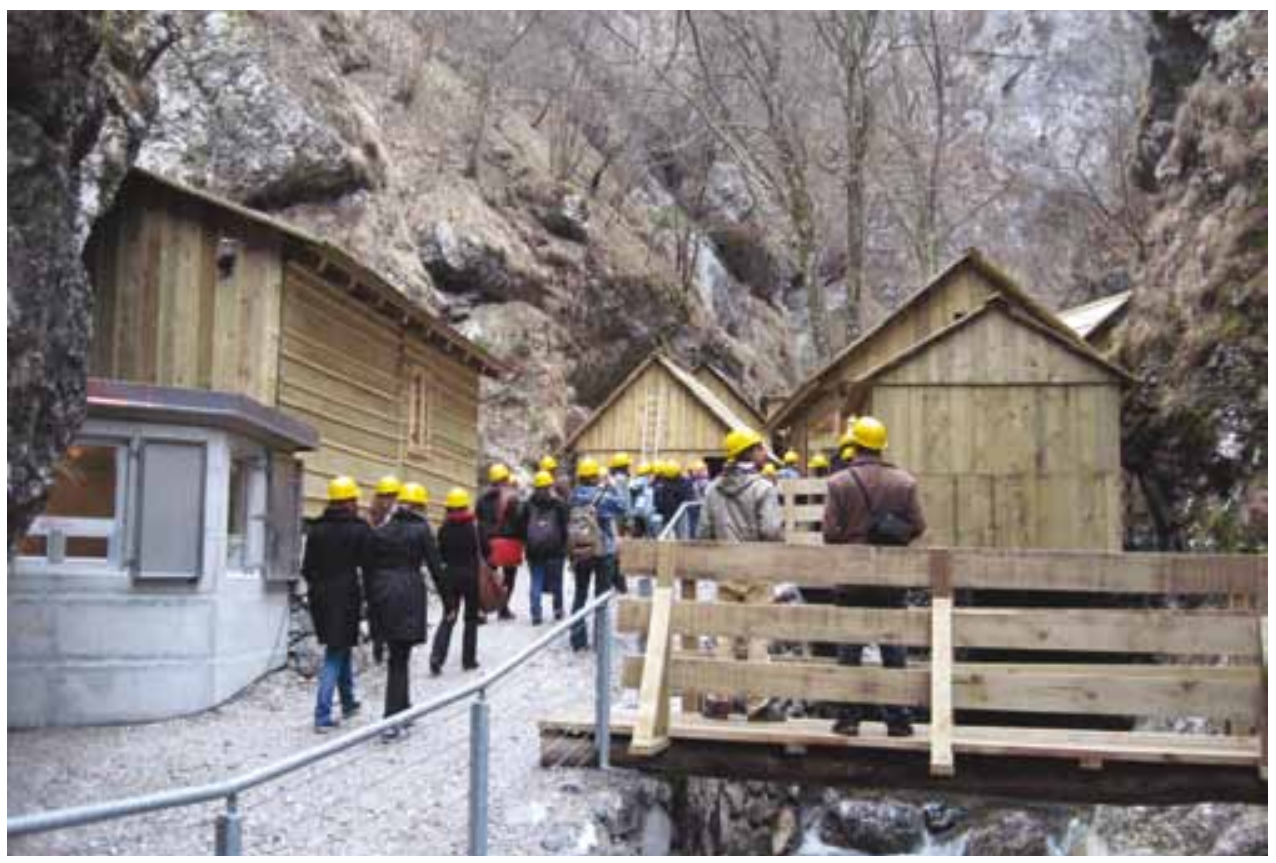

Figure 6. The Franja Partisan Hospital, a monument of national, European and global importance. Any visitor, uniformed or informed, would have a hard time accepting the "forced" safety rail made of stainless-steel. The monument has thus been "given" a functional accessory (a safety feature for visitors) which is to say at the least extremely intrusive (photo: V. Hazler, 2010).

experienced museologists and ethnologist presented harsh remarks regarding presumably incorrect programme policy in the Rogatec Open-Air Museum.They were most concerned about the so-called "rogaški cugec", a train that, similarly as is done in Ljubljana and numerous coastal towns, transported passengers from the Rogaška Slatina Health Resort to the museum and back. They were also very critical of the local population, the members of the Association for the establishment of the Rogatec Open-Air Museum, who saw the critique as a personal attack on their ethically indisputable amateur work that among other things contributed to the establishment of the largest open-air museum in the country. In the mentioned example the expert ethical code failed completely. It is therefore reasonable to ask what the purpose of the confident experts was. Due to this event, among other things, the cooperation of the Rogatec inhabitants and the Museum of Recent History Celje ceased completely for a number of years.

Ethics are often greatly challenged also in cases of business cooperation in certain special forms of the already mentioned assessment and interpretation of cultural heritage. An amateur approach questionable from the expert aspect is nowadays very common in this area; this explains why we are confronted with the phenomenon of inventing a new, imaginative and often distorted tradition of all types. On the one hand, some approaches are developing into disputable commercial interpretations of cultural tradition supported 


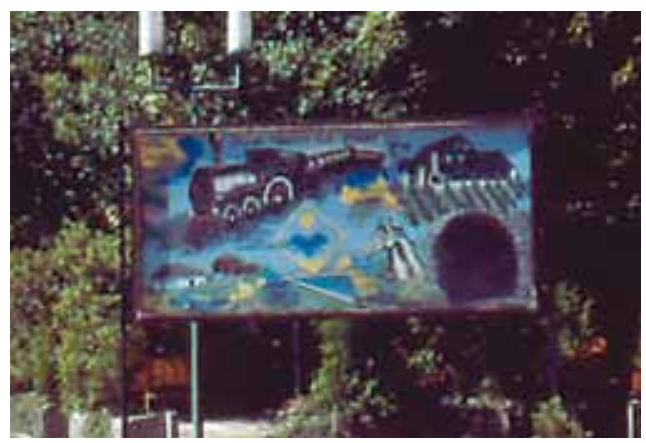

Figure 7. The advertising board in Rogaška Slatina promoting "Rogaški cugec" - a train that used to take visitors to the Rogatec Open-Air Museum until 1993. In that year, some harsh critics presented by the so-called "experts on the tourist interpretation of cultural heritage" that participated in student research workshops dissuaded the owner from further use of the train for transportation of the wealthy guests from the Health Spa to the museum. Nowadays, twenty years later, such train would undoubtedly be popular as the Rogaška Slatina Spa is full of eager Russian, Ucranian, Italian and other wealthy tourists. It could be said that reckless criticism, some twenty years ago, prevented the places beneath the Donačka gora mountain from earning a considerable amount of money (photo: V. Hazler, 1993).

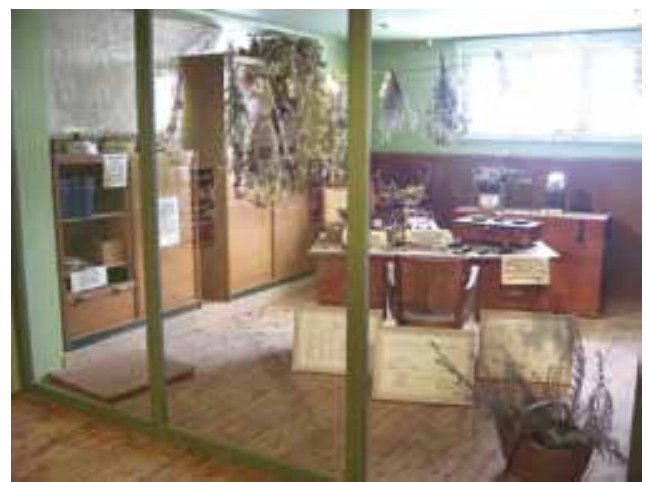

Figure 8 . The contemporary museum exhibition of the hop-growing culture is still a work in progress. The exhibition will undoubtedly require a thorough adjustment of the museum presentation as the exhibition premises seem much too perfect (photo: V. Hazler, 2010). by new globalised forms of revelry, the desire to please and be attractive. On the other hand, others are becoming technologically updated physical presentations of cultural heritage. These are the more or less unethical forms of reception and perception of cultural heritage that we were confronted with at the Hop Growing and Brewing Industry Eco-Museum of Slovenia in Žalec. Its establishment, in the first phase, was planned by a group of competent ethnologists, researchers, museologists, conservators and architects. Between 2005 and 2008, the group prepared a detailed programme of design and the construction of the museum, which was based on the central museum collection of the hop growing and brewing industry with the seat in Žalec and on the activities of several dislocated units of museum collections and other characteristic forms of tangible and intangible heritage in all six municipalities (Žalec, Prebold, Polzela, Tabor, Vransko, Braslovče) of the Lower Savinja Valley. With the help of the local development agency the holders of the project presented the planned activities to the people across the municipalities at field workshops. The project continued to evolve uninterrupted until a new public tender for the acquisition of funds for its construction was organised. At that time a new, less expensive expert group was selected. At first the group was quite successful and continued the work of the previous group between 2009 and 2010.

They also set-up a museum collection in a former drying room of the Institute for hop growing and the brewing industry of Slovenia in Žalec. In the former storage 
premises in the multi-storey building museum items were sorted for individual thematic collections. They formed an interesting museum image and arranged a nice reception area in the ground floor of the museum. The group also prepared premises for different types of workshops for children and adult visitors in the first storey. However, they did nothing regarding the operation of the dislocated units, especially the arguable presentations of the museum on the internet designed by amateur interpreters of cultural heritage - the latter did not have the slightest idea of what an ethical code of expert cooperation is. They have published a number of romantic and nostalgic presentations of the hop growing cultural heritage, particularly about the hop plant collection which has nothing in common with the actual work done in a hop field. Another novelty, disputable from ethical and expert aspects appeared. It seems that nowadays nobody is concerned by the fact that the comprehensive understanding of an eco-museum mission is mistaken for the production of food and herbs. Therefore the critique of such unethical practice is quite appropriate, for this is a project of great dimensions with large physical support from the state and European Union funds.

\section{CONCLUSION}

The purpose of this article is to stress the necessity of an integral approach to the study of cultural heritage, regular implementation of ethical principles and the code of ethics when dealing with heritage and, above all, the need to comply with expert decisions which must become a normal way of conducting all forms of cooperation between experts and amateurs. The heritage protection issue opens many questions that are also important for the development of a positive attitude towards heritage and for the contribution to its modern reception and perception, in particular in the general public. Hence theoretical reflections on the subject are more than welcome.

\section{REFERENCES}

Eko-muzej

2011 Eko-muzej hmeljarstva in pivovarstva (Hop Growing and Brewing Industry Eco-Museum) (http:// www.ekomuzej-hmelj.si/si/; 8 December 2011).

Hazler, Vito

1999 Podretialiobnoviti? Zgodovinski razvoj, analiza in model etnološkega konservatorstva na Slovenskem. Ljubljana: Založba Rokus.

2008 Varstvo kulturne (stavbne) dediščine. (Raz)korak med teorijo in prakso. Glasnik SED 43 (3-4): 9-17.

Kolizej

2011 Kolizej bo padel (Kolizej will faill) (http://www.delo.si/novice/slovenija/kolizej-bo-padel-v-prihodnjem-tednu.html; 8 December 2011). 
Lah, Ljubo

2001 Od arhitekturnega konzervatorstva, obnove in prenove do integralnega varstva dediščine. Urbani izziv 12 (1): 31-45.

Maroević, Ivo

1986 Sadašnjost baštine. Zagreb: Društvo povijesničara umjetnosti Hrvatske.

Odlok o strategiji

2011 Odlok o strategiji prostorskega razvoja Slovenije (Decree on Spatial Development Strategy of Slovenia) (http://www.uradni-list.si/1/objava.jsp?stevilka=3397\&urlid=200476; 23 December 2011).

Partizanska bolnica Franja

2011 Partizanska bolnica Franja (Franja Partisan Hospital) (http://sl.wikipedia.org/wiki/Slovenska_ vojna_partizanska_bolnica_Franja; 8 December 2011).

Sanz, Nuria

2002 Living Wooden Culture throughout Europe. Strasbourg: Council of Europe.

Šestan, Ivan

1990 Vino i tradicija. Zagreb: Etnografski muzej u Zagrebu.

Vidic, Jana idr.

2006 Sistem varstva narave v Sloveniji. Ljubljana: Ministrstvo za okolje in prostor.

Zakon o kulturni dediščini

2011 Zakon o kulturni dediščini ((Law on Cultural Heritage) (http://www.uradni-list.si/1/objava. jsp?stevilka=485\&urlid=200816; 23 December 2011).

\section{PERCEPCIJA KULTURNE DEDIŠČINE IN VARSTVO SPOMENIKOV}

Na vseh varstvenih področjih dozoreva spoznanje o nujni celoviti in celostni obravnavi kulturne dedišcine. Etnologi se $v$ teh prizadevanjih vse bolj uveljavljamo, saj v tem vidimo priložnosti za uveljavitev učinkovitih metodoloških in programskih izhodišč, ki so osrednjega pomena, da dedisčino prepoznavamo celovito in ne več izključujoče enostransko, zgolj iz vidika časa, likovne izraznosti ali arbitekturne pomembnosti. Še posebej se je takšna celovitost v metodološko razsirijenem obsegu programsko natančno izostrila sredi 90. let 20. stoletja, ko je predvsem v delovnem okolju etnologov-konservatorjev dozorelo prepričanje o oblikovanju glavnih meril za prepoznavanje, vrednotenje in fizično obnovo kulturne dedišcine. Iz preteklih spomeniškovarstvenih izkušenj so prav etnologi razvili razmeroma uporabna merila, ki so postala vodilo sistemskega varstva dedišcine. V ta namen je avtor tega besedila, sicer pa dolgoletni konservator-etnolog, razvil merila, kot so geografsko ali prostorsko, zgodovinsko ali časovno, likovno ali estetsko, etnološko-socialno in gradbeno-razvojno merilo. Pozneje jim je dodal merilo funkcije in merilo vešcin in znanj ter umetniške ustvarjalnosti.

Merila so pomembna pri vseh ravnanjih $z$ dedišcino, in sicer zlasti v razmerju med recepcijo oziroma sprejemanjem in prepoznavanjem ter percepcijo oziroma nadaljnjimi posegi v dedišcino in interpretacijo njenih oblik in vsebin. Pri teh postopkih v spomeniškovarstveni praksi pogosto prihaja do spornih konservatorskih in prezentacijskih odlocitev, ki jih najpogosteje spremljajo še skrajno sporne vgraditve sodobnih ("nujnih funkcionalnih") dodatkov, ki kulturni dedišcini 
bistveno zmanjšajo njen celovit kulturni pomen. Takšni dodatki rušijo temeljni pomen varstva dediščine, zato se ob njih kritičnemu opazovalcu upravičeno postavlja vprašanje, zakaj se stroka odločneje ne upre raznim projektantskim in kapitalskim lobijem in dejansko brez prepotrebnega "konservatorskega sramu« sprejema različne "implantacije«, kot so na primer dvigala na pročeljih ali v notranjosti spomeniških objektov, zasteklitve s kovinskim stavbnim pohištvom, žičnate ograje $v$ prvobitnem naravnem okolju, masivni prizidki, izjemne količine betona in železja v ostenjih stavb in zunanjih opornih zidov, sodobni zaščitni premazi za les in kovine, sodobne tehnologije obdelave gradiv in še vrsto drugih motečih sestavin. Zato je sprejemanje takšnih in podobnih sodobnih konservatorskih interpretacij dedišcine strokovno zelo sporen ukrep, ki se zaenkrat pri nas (se) ne sankcionira. Posledice so večkrat tako hude, da se upravičeno labko vprašamo, ali kak spomenik lokalnega ali državnega pomena po takšni "razvojni prenovi« še ima vrednost kulturnega spomenika.

Celostnega varstva dedišcine, ki ga v spomeniškem varstvu razvijajo predvsem v smislu fizičnega ohranjanja zavarovanih objektov, ni mogoče uspešno uveljavljati in razvijati brez upoštevanja in vključevanja cele vrste dedišcinskih pojavov, med katerimi so zlasti pomembni njihovi nesnovni vidiki. Ti so osrednjega pomena pri vseh postopkih recepcije in percepcije kulturne dedišcine, saj resnično kakovostne obnove niso mogoče brez upoštevanja historičnih znaj in večin obdelave gradiv in vseh drugih delovanj. Za to pa so najprej potrebne temeljite raziskave in šele nato ustrezne prezentacije in interpretacije. Tega se slovensko institucionalno konservatorstvo vse premalo zaveda, saj večkrat odpovedo temeljna etnična načela in ugotovitve, kaj je prav in kaj je napak. Č bi si takšna vprašanja stroka zastavljala redno, bi bilo zagotovo bistveno manj nepremišljenih "implantacij«, ki ob uvajanju množice sodobnih tehnologij spomenike in dediščino lahko za vedno pohabijo. Uničenih kulturnih spomenikov imamo kljub dobro razviti spomeniškovarstveni dejavnosti in relativno dejavni civilni iniciativi vendarle nekoliko preveč.

Assoc. Prof. Dr. Vito Hazler, Department of Ethnology and Cultural Anthropology, Faculty of Arts, University of Ljubljana, Aškerčeva 2, SI - 1000 Ljubljana, Slovenia, vito.hazler@ff.uni-lj.si 